\title{
Chapter 9 \\ POTENTIAL OF EDUCATIONAL INNOVATIONS IN FORMING DIGITAL COMPETENCE OF ENTREPRENEURS IN UKRAINE
}

\author{
Hrebeshkova O. M., Kyzenko O. O.
}

\section{INTRODUCTION}

The expansion of the post-industrial economy exacerbates the problem of the formation of digital competence as an integral characteristic of a modern specialist in any field of activity. This problem acquires particular relevance in the context of the development of the business environment as a driver of economic development with its inherent innovative type of thinking, an increased level of riskiness, and high dynamics of organizational and business processes.

Digitalization is a global trend in the society development in the 21 st century. T. Mesenburg formulated three main components of the digital economy concept in $2001^{1}$ :

1) supportive infrastructure (hardware, software, telecommunications, networks, etc.);

2) electronic business (business through computer networks);

3) e-commerce (transfer of goods online).

According to PWC experts who conducted digital economy development studies in 150 countries, Ukraine was in the group of 28 transformational countries - the penultimate on the way to the highest level $^{2}$.

In order to accelerate the spread of information and communication technologies in Ukraine, in January 2018, the Concept of Development of the Digital Economy and Society of Ukraine for 2018-2020 was approved $^{3}$.

The defining directions for the development of a digital society are:

\footnotetext{
${ }_{2}^{1}$ Mesenbourg, T. L. (2001). Measuring the Digital Economy. U.S. Bureau of the Census.

Maximizing the impact of digitization. PWC. Retrieved Nov. 10, 2019, from https://www.strategyand.pwc.com/media/file/Strategyand_Maximizing-the-Impact-of-Digitization.pdf

${ }^{3}$ Kontseptsiia rozvytku tsyfrovoi ekonomiky ta suspilstva Ukrainy na 2018-2020 roky. [Concept of development of digital economy and society of Ukraine for 2018-2020.]. Retrieved Nov. 10, 2019, from http://me.gov.ua/Documents/Download?id=f9605f2f-c4a8-46f3-aee9-4a7f40dc9b9b [in Ukrainian]
} 
1) bridging the digital divide (unevenness) due to the development of digital infrastructures;

2) training in general and professional digital competences;

3 ) introduction of the concept of "digital" jobs;

4) digitalisation in the real sector of economy (transition to Industry 4.0);

5) implementation of digital transformation projects, including in the fields of public security, education, health care, tourism, edemocracy, environmental protection, urban life, etc ${ }^{4}$.

It is obvious that a successful solution of the tasks set is impossible without the preparation of appropriate specialists who: are able to think creatively; tuned to the introduction of innovative solutions; willing to take risks in conditions of high unpredictability; mobile in their behavior. They are the characteristics that distinguish entrepreneurs - the creative class of the post-industrial economy.

\subsection{Innovation in education as a necessary prerequisite for the training of new generation specialists}

According to the Global Entrepreneurship Index, as of 2017, the leaders are the United States, Switzerland and Canada. Ukraine ranks 66th out of 137 countries in the world and 33rd out of 41 in Europe ${ }^{5}$. Ukraine's neighbors in this ranking are Thailand and Peru. The leaders are the USA, Switzerland and Canada. According to the experts of this report, entrepreneurship is a dynamic, institutionally implemented system of entrepreneurial relations, entrepreneurial abilities and entrepreneurial aspirations of individuals who manage the distribution of resources by creating and operating new businesses. Accordingly, to improve the entrepreneurial profile of the country, it is necessary to increase the potential of "entrepreneurial relations, entrepreneurial abilities and entrepreneurial aspirations", which, we believe, is due to the qualitative transformation of the education system.

According to vivid expression Jack Ma, Alibaba Group heads, what we teach our children today may tomorrow cause them to lose their jobs. Everything that we learn according to the old scheme of education, remembering knowledge, learning computing - all this machines can do

\footnotetext{
${ }^{4}$ Kontseptsiia rozvytku tsyfrovoi ekonomiky ta suspilstva Ukrainy na 2018-2020 roky. [Concept of development of digital economy and society of Ukraine for 2018-2020.]. Retrieved Nov. 10, 2019, from http://me.gov.ua/Documents/Download?id=f9605f2f-c4a8-46f3-aee9-4a7f40dc9b9b [in Ukrainian]

${ }^{5}$ Global Entrepreneurship Index. Retrieved Nov. 21, 2019, from http://thegedi.org/countries
} 
better. We must restructure the education system. We must teach our children to be innovative and creative. ${ }^{6}$

Ukraine ranks the 45th place in quality of education. Less than $15 \%$ of Ukrainian citizens consider our education really of high quality. $58 \%$ believe that a diploma in higher education does not provide an opportunity to get a good job. $22.8 \%$ is the youth unemployment rate in Ukraine ${ }^{7}$.

The leaders of the education quality rating are the USA, UK, Germany and Australia. What causes the success of education in these countries? The answer to this question can be found in the words of Burton Lee, a professor of Stanford University: "Every year, around 500 startup teams and $40 \%$ of participants in these teams are students, $10 \%$ are associate professors and professors, $50 \%$ are graduate students. $60 \%$ of these teams focus on research while developing their startups, and $40 \%$ promote university development and their own ideas that were born on campus. In the United States, students are the most important component of building innovative businesses. In many European and post-Soviet universities, students play a passive role in innovative developments. At Stanford University, students are taught to be leaders, entrepreneurs, founders of companies. They learn to be creative developers because the share of student work in the development of new progressive products is very large. The best way to educate students about innovative entrepreneurship is to engage professionals who are not aware of it. At Stanford, we don't teach entrepreneurship theory. We teach students to create real companies. We focus students' attention on developing real products and testing them in the real market. One of the most important approaches to student learning is the transfer of knowledge, not from professors, but from other students. Student clubs are a very important component of Stanford University's ecosystem. Entrepreneur clubs are an important place where students, team leaders and founders of stratagemes meet and discuss problems. This is where leadership skills are taught. Each club deals with its financing, independently attracting investors and implementing developments. We

\footnotetext{
${ }^{6}$ Karpenko, O. (2017) Hlava Alibaba Dzhek Ma - ob ekonomyke budushcheho: "Perestante nadeiatsia na proyzvodstvo v sozdanyy rabochykh mest". [Alibaba CEO Jack Ma, on the economy of the future: "Stop hoping for manufacturing in job creation."]. Retrieved Oct. 23, 2019, from https://ain.ua/2017/09/21/dzhekma-ob-ekonomike-budushhego/ [in Russian]

7 Ukrayna na 42-m meste v reitynhe ynnovatsyonnukh ekonomyk myra. Kak tak vyshlo? [Ukraine is at 42nd place in the ranking of innovative economies in the world. How did it happen?]. Retrieved Nov. 9, 2019, from https://businessviews.com.ua/ru/economy/id/ukraina-na-42-m-meste-v-rejtinge-innovacionnyhekonomik-mira-kak-tak-vyshlo-1460/ [in Russian]
} 
have learned to blend university culture with the culture of innovation in one place. Ukraine has a very good scientific and engineering culture and one of its main tasks is to combine this culture with the culture of innovation. This should be the main task of economic development of the country"

One of the most promising ways of educating entrepreneurs in Ukraine is to implement educational programs of different levels of training for the general population. Such programs should be developed on a comprehensive basis, which provides:

1) implementation of the principle of "life-long learning" implementation of educational programs for different age categories of citizens, including the use of models of cross-age groups;

2) the transition to problem-based learning (PBL) - learning in which real complex problems are used as an educational tool. Taskbased learning encourages critical thinking and problem-solving skills $^{9}$ and provides genuine experience that fosters an active learning process, helps systematize knowledge, and naturally integrates learning in school and real life ${ }^{10}$. Common formats of PBL are case studies, role-playing games and simulations (modeling of certain processes and facts);

3 ) extension of the competence approach in education, which is manifested in the orientation of the educational process to the achievement of learning results due to the formation of general and professional competencies in its applicants. The basic requirements for the competences of vocational education are as follows: a) the competences should be clearly understood by all stakeholders (students, teachers, employers, employees of management and supervisory bodies); b) competences are diagnosed with the use of qualimetric tools (a set of measuring instruments), which allows to rank the degree of their achievement in the form of a point evaluation; c) the set of competences should be minimized on the grounds of adequacy of achievement of the integral purpose of education and tasks of professional activity, defined by the standard;

\footnotetext{
${ }^{8} 5$ hlavnykh urokov Kremnyevoi Dolyny. [5 main lessons of Silicon Valley]. Retrieved Nov. 1, 2019, from http://www.startup.org.ua/2016/04/5.html?m=1 [in Russian]

9 Savery, J. R. (2006). Overview of Problem-based Learning: Definitions and Distinctions. Interdisciplinary Journal of Problem-Based Learning, 1(1).

${ }^{10}$ Taşoğlu, A. K. \& Bakaç, M. (2014). The Effect of Problem Based Learning Approach on Conceptual Understanding in Teaching of Magnetism Topics. Eurasian Journal Physics \& Chemistry Education 6(2): 110-122.
} 
4) saturation of traditional educational programs with the information and communication component due to the introduction of appropriate tools not only in the teaching process (for example, in the form of distance or e-learning), but also in the "content" of the educational process - through the acquisition of special information products (such as ERM-systems);

5) development and implementation of special educational products (long-term and short-term programs, trainings, seminars, etc., including in the latest electronic formats), directly aimed at studying the laws of the digital economy and mastering the skills of working with digital infrastructure (SMART-city, etc.).

Researching the digital competence of a modern man, it should be borne in mind that in the perspective of 2020, three generations stand out in the evolution of e-learning.

E-learning 1.0 focuses on creating effective teaching content through a predominantly static website and Learning Management System (LMS) (for example, MOODLE).

E-learning 2.0 builds on the capabilities of social services (blogs, messengers, networks) and focuses on providing the facilitator with group communication (including collaboration tools such as Microsoft OneNote Class Notebook and Microsoft Teams).

E-learning 3.0 is a generation of virtual reality in the learning process with the involvement of artificial intelligence (for example, Microsoft Kinect, Second Life) focused on personal learning. The trend of individualization and "networking" of learning is being observed, with a fundamental change in the role of the teacher in the educational process. Are domestic university teachers ready for these challenges?

Study of e-learning practice in Ukrainian universities ${ }^{11}$ certifies that today we are quite confident in the acquisition of first generation training systems (distance and blended learning on the MOODLE platform). However, the transition to second- and third-generation systems remains a promising task.

The powerful potential of the transition to the second generation of e-learning lies in the model of social computing (social computing) system integration of social sciences and computer Internet

\footnotetext{
11 Pasichnyk, O. (Ed.) (2017). Praktyky zastosuvannia zmishanoho navchannia u vyshchii shkoli: analitychnyi zvit za rezultatamy opytuvannia [The practice of capturing the meaning of food in high school: an analytical call for the results of the study]. Tsentr navchalnykh ta innovatsiinykh tekhnolohii Ukrainskoho katolytskoho universytetu Retrieved Aug. 16, 2018, from http://er.ucu.edu.ua/handle/1/1124 [in Ukrainian]
} 
technologies, implemented by appropriate tools - blogs, social networks, wiki, virtual reality, etc. that provide e-social interaction and collaboration on the Internet ${ }^{12}$.

Social computing is recognized as the basis for the creation of various kinds of global communities, networks focused on achieving common goals and satisfying the individual interests of their participants, can provide "glocal" (from "global" + "local") behavior of all (and at the same time each separately) educational participants of the process.

Analyzing the challenges facing social computing researchers ${ }^{13}$, we can say that the introduction of the model of the same name in the educational process of the university involves the search for answers to the following questions ${ }^{14}$ :

- how does the educational process change the Internet space and on what new methodological foundations does it build?

- how are the roles of teacher and student transformed in the creation and functioning of a virtual social space?

- how does the behavior of people in the educational virtual space (online) change and what is the impact of such behavior on the real (offline) educational space (the process of the so-called "devirtualization")?

\subsection{The practice of implantation educational innovations in Ukrainian universities}

Educational innovation remains a priority at all levels of education management. The reform of general higher education continues, the key provisions of which are manifested in:

- updating the content of educational programs, including as a result of focusing on the formation of competencies of the

${ }^{12}$ Yskandarova, D. M., Hulova, Z. A., Davlatmyrova, M. B., Karymova, N. Y., Mukhtorov, Z. M. \& Fomyn, A. Yu. (2016). Yssledovanye tolerantnosty $v$ molodezhnoi srede Tadzhykystana (lynhvystycheskye aspekty). [The study of tolerance in the youth environment of Tajikistan (linguistic aspects)]. Moskow: Yzdatelskyi dom Akademyy Estestvoznanyia. [in Russian]

${ }^{13}$ Brodovskaia, E. V., Azarov, A. A., Dombrovskaia, A. Yu. \& Dmytryeva, O. V. (2014). Sotsyalnyi kompiutynh: istoryia, metodolohyia, yssledovatelskye proekty. [Social computing: history, methodology, research projects.] Doklad na 18-m zasedanyy semynara "Metodolohycheskye problemy nauk ob ynformatsyy". Moskva, YPHYT MHHU ym. M.A. Sholokhova. Retrieved Sep. 1, 2018, from https://docplayer.ru/33551421-Socialnyykompyuting-istoriya-metodologiya-issledovatelskie-proekty.htmt [in Russian]

${ }^{14}$ Yskandarova, D. M., Hulova, Z. A., Davlatmyrova, M. B., Karymova, N. Y., Mukhtorov, Z. M. \& Fomyn, A. Yu. (2016). Yssledovanye tolerantnosty $v$ molodezhnoi srede Tadzhykystana (lynhvystycheskye aspekty). [The study of tolerance in the youth environment of Tajikistan (linguistic aspects)]. Moskow: Yzdatelskyi dom Akademyy Estestvoznanyia [in Russian] 
entrepreneurial type - critical and strategic thinking, leadership and partnership, digital competence, and the like;

- the introduction of distance learning as a self-sufficient and autonomous form of learning at all levels of education;

- the spread of e-learning practices in the educational process communication with students through social networks, support for traditional offline courses on MOODLE (as well as on the basis of Google Class and Class Notebook Microsoft Office 365);

- organization of the university's internal communication system (in particular, based on Microsoft Ofice 365);

- expanding the presence of universities in the digital space - sites, social networks on the Internet, open online courses.

It is no longer an innovation to enroll in student learning outcomes for taking open online courses on the platforms Prometheus, Coursera, Udemy and others. Ukrainian teachers are actively involved in creating their own online courses (the authors have personal experience creating such courses on Udemy $^{15}$ or YouTube ${ }^{16}$ ). Quite common in the organization of the educational process is the use of electronic communication tools such as email, social networks (Facebook, LinkedIn), instant messengers (Viber, Telegram). For the effectiveness of the educational process, teachers use the opportunities that provide such electronic services as Skype, YouTube, Padlet, Trello, Kahoot. However, it should be recognized that the results of the modernization of the education sector in Ukraine remain contradictory. We illustrate this with the data obtained by us during the relevant studies.

In November 2018, an online survey of teachers of the Faculty of Economics and Management of Vadim Getman Kiev National University of Economics was conducted in order to identify practices and assess the willingness of teachers to spread the Blended Learning model in the faculty ${ }^{17}$.

\footnotetext{
15 Hrebeshkova, O. M. (2017). Mikroekonomika: pochatkovyi riven. [Microeconomics: entry-level]. Retrieved Nov. 10, 2019, from https://www.udemy.com/microeconomics_ua. [in Ukrainian]

${ }^{16}$ Kyzenko, O. O. (2017). Kurs video-lektsii "Korporatyvne pidpryiemnytstvo". [Course of video lectures "Corporate entrepreneurship".]. Retrieved Nov. 10, 2019, from https://www.youtube.com/ watch?v=Leal95BNOBQ\&list=PLgBzM3YOp1EGBcMs8xrNaedoTEcUJgkzh [in Ukrainian]

${ }^{17}$ Hrebeshkova, O. M. (2018). Praktyka zmishanoho navchannia v navchalnomu protsesi na fakulteti ekonomiky ta upravlinnia DVNZ "KNEU imeni Vadyma Hetmana". [The practice of blended learning in the educational process at the Faculty of Economics and Management of the KNEU named after Vadym Hetman]. Dopovid na zasidanni vchenoi rady fakultetu (22.11.2018 r.). Retrieved Nov. 2, 2019, from https://drive.google.com/file/d/1Hk1783HCvhLfMRUgU8hWaHvANCbPpqLv/view?usp=sharing [in Ukrainain]
} 
The questionnaire included 30 questions on four blocks: general sample characteristics (6 questions); blended learning tools (10 questions); blended learning technology (7 questions); willingness to implement online training (7 questions). 59 teachers took part in the survey (35\% from salaried scientific and pedagogical personnel of the Faculty), of these, $8.6 \%$ are professors, $69 \%$ are associate professors.

Based on a generalization of the answers received, it was found that $25 \%$ of the participants surveyed have distance learning courses (which are delivered on online platforms), the vast majority of which are prepared for undergraduate students. Only $14 \%$ of the faculty interviewed (or 56\% of those with distance learning) use the MOODLE platform to support the learning process for full-time and part-time students, while $61 \%$ of the respondents do not use MOODLE at all - one of the most common Learning Management System class platforms (LMS). It was revealed that in the practice of blended learning "passive" online tools (e-mail, cloud storage, instant messengers, social networks) dominate, with the help of which educational content is only heard by students. Even those tools (messengers and social networks) that can be used for active collaboration are not implemented for their intended purpose - to provide bi-directional interaction.

Interesting was the unpopularity of online testing as a form of knowledge control: only $7 \%$ of faculty (or $29 \%$ of those with distance courses) use online testing, with the vast majority of them only sporadically (systematically).

The most common form of creating educational online content is slide lecture notes, which $76 \%$ of the interviewed professors have reported using. Video content is systematically used by only $12 \%$ of those surveyed, and only original units create their original video content.

Teachers rarely recommend that students take Massive Open Online Courses (MOOC): only 15\% of those surveyed admit that they use it to teach their subjects. According to the students, the online courses they have completed have proved to be useful for mastering the curriculum of the discipline. The average mark on the current academic performance of these students is higher (an average of 14.6 points on a 100-point scale) than those who did not take online courses. It must be acknowledged that its results are generally positive.

It turned out that the vast majority of respondents $(71 \%)$ do not have the practice of holding online conferences (webinars, consultations) 
with synchronous communication (in real time). And even those teachers (20\% of respondents) who noted the presence of such experience admit that this practice is solitary and is used occasionally.

Assessing their readiness to implement online training, the survey participants stated that they had passed or are undergoing (at the time of the survey) special training (42\% of respondents), of which $81 \%$ of respondents are ready to work on the model of distance education. Of those who did not undergo special training, the vast majority of teachers (73\%) expressed their interest in further building up their digital competence.

A separate block of research requests is formed by questions of motivation and work efficiency of e-learning participants, primarily teachers and students. Our experience in organizing the teaching of a discipline on the model of social computing comes down to the implementation of two educational projects - a joint Ukrainian-Canadian educational and research project of collaborative learning "Cultural Dimensions and Professional Strategies" (2015-2016) ${ }^{18}$ and creating online courses on the Microsoft OneNote Class Notebook platform (2017) ${ }^{19}$.

The results of a study of the digital competence of the participants in the educational process at the Vadim Getman Kiev National University of Economics, whose purpose was to identify and assess readiness for fully online collaborative learning. The study involved 244 participants, for whom, based on their online questionnaire, measure digital experience and confidence across four categories of humancomputer activity. To assess readiness, reported levels of competencies were related to the three dimensions of successful collaborative learning described by the Community of Inquiry model. Despite some key differences between students and teachers, general findings include moderate-to-low levels of self-reported technical, social and informational competency, accompanied by consistently low levels of epistemological competency. These findings suggest that neither students nor teachers are adequately prepared for achieving high levels of social, cognitive and teaching presence in a fully online learning

\footnotetext{
18 Blayone, T. J. B., Mykhailenko, O., vanOostveen, R., Grebeshkov, O., Hrebeshkova, O., \& Vostryakov, O. (2018). Surveying digital competencies of university students and professors in Ukraine for fully online collaborative learning. Technology, Pedagogy and Education, 27(3): 279-296. http://dx.doi.org/ 10.1080/1475939X.2017.1391871

${ }^{19}$ Hrebeshkova, O. M. Yak stvoryty onlain-kurs v Microsoft OneNote Class Notebook. [How to Create an Online Course in Microsoft OneNote Class Notebook |]. Retrieved Oct. 24, 2019, from https://www.udemy.com/onenote-classroom/learn/v4/ overview. [in Ukrainian]
} 
environment. It is recommended that digital-competency development become an educational priority. ${ }^{20}$

Drawing on this experience of implementing e-learning and blended learning ${ }^{21}$, we consider it possible to assert that the most promising areas of work to introduce a model of social computing in the educational activities of a domestic university are:

- Deployment of a full-fledged communication and knowledge platform at the university (for example, on the Microsoft Office 365 platform), which opens up new horizons for the formation of digital competence of all participants in the educational process and promotes the spread of a culture of electronic communication;

- creation and use of online courses (in the future, clusters of educational online projects) with integrated online communication tools (video blogs, collaboration spaces, social networks), which allows you to generate new knowledge jointly by all participants in the educational process and in synchronous mode (and not just asynchronous) communication;

- expanding the membership of the educational process by attracting external experts and specialists (potential employers, foreign researchers, government and public figures, etc.) using the Internet. In the future, the implementation of this direction may turn into the introduction of a full-fledged dual online education.

\subsection{Problems and prospects of entrepreneurial education in Ukraine in the digital economy}

What challenges do entrepreneurship face in a digital economy? Without claiming to be a comprehensive classification, we note only the most obvious of them.

1. The lack of deep entrepreneurial culture in Ukrainian society due to objective historical processes of formation of the statehood of Ukraine. The seventy-year domination of a planned economy still affects the thinking patterns of domestic businessmen and restrains entrepreneurial thinking with a "traditional" framework. The values of

20 Blayone, T. J. B., Mykhailenko, O., vanOostveen, R., Grebeshkov, O., Hrebeshkova, O., \& Vostryakov, O. (2018). Surveying digital competencies of university students and professors in Ukraine for fully online collaborative learning. Technology, Pedagogy and Education, 27(3): 279-296. http://dx.doi.org/10.1080/1475939X.2017.1391871

${ }_{21}$ Hrebeshkova, O. M., Grebeshkov, O. M. \& Kyzenko O. O. Onlain-kurs "Zmishane navchannia: retsepty - prosto ta smachno! Znaiomstvo z "kukhneiu" zmishanoho navchannia". [Blended Learning: Recipes - Easy and Delicious Online Course! Getting to know the blended learning kitchen."]. Retrieved Nov. 4, 2019, from https://blendedlearning.teachable.com/ p/blendedlearningrecepies. [in Ukrainian] 
open competition and innovative thinking are only being formed in Ukrainian society, as evidenced by the evaluative profile of cultural measurement model meters G. Hofstede for Ukraine (Figure 1).

\section{\begin{tabular}{|l|l|l} 
Germany $\times$ & Ukraine* $\times$ & United States $\times$ \\
\hline
\end{tabular}}

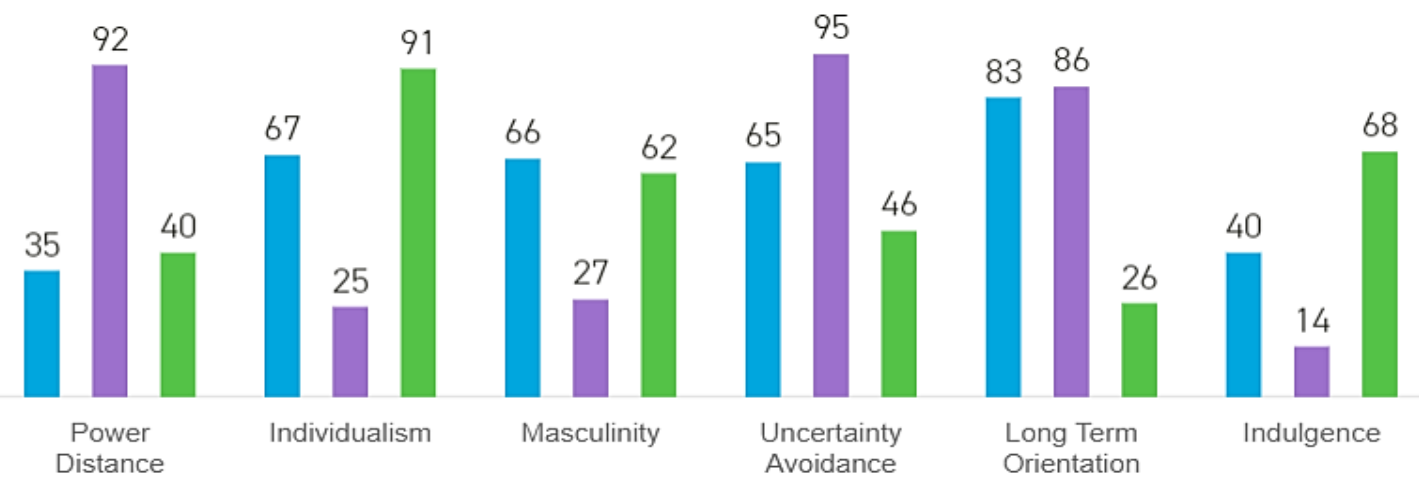

Figure 1. Profile of cultural dimensions for Ukraine by model G. Hofstede ${ }^{22}$

2. The dominance of traditional (mainly inherent in the industrial economy) technologies and training models based on the storage and accumulation of knowledge, rather than the formation of competencies and the development of various abilities. Outdated standards of Ukrainian higher education do not keep pace with technological progress, innovation and the growing demand for relevant specialists in the industry. The educational system continues to focus on lectures and exams, not paying enough attention to the realities of practical professional life. Therefore, it is hardly possible to count on graduates as future successful and efficient workers if their training is based on outdated methods and anachronistic educational models. The failure of Ukrainian higher education institutions to provide graduates with a level of knowledge and skills that is in demand in the modern economy is evidenced by the fact that, given the almost 76 percent coverage of the population with higher education (14th place from 140 countries, after Greece, the USA, Finland, Germany, etc. ), its quality remains low (54th place), and according to the Global

22 Compare Countries. Hofstede Insights. Retrieved Nov. 16, 2019, from https://www.hofstedeinsights.com/product/compare-countries/ 
Competitiveness Index (GCI) of the World Economic Forum Ukraine for 2015-2016. ranked only the seventy-ninth among 140 countries. $^{23}$

3 . There is still limited use of online learning tools due to the imperfection of the digital infrastructure. The low quality of the Internet and the insufficient provision of educational institutions with appropriate tools preclude the effective development of e-learning and hinder the initiative of innovative teachers.

4. Low motivation of applicants to education in entrepreneurship education and lack of awareness by teachers of the value and content of such education.

The solution to these problems is seen by us in the following areas.

1. The development of an entrepreneurial culture is possible as a result of the popularization of an entrepreneurial way of thinking, starting from childhood. As our experience of career guidance with schoolchildren shows, modern children (even the elementary grades) are open to entrepreneurship, set up for creative thinking, are interested in studying entrepreneurship models. The fact that the age structure of participants in career guidance events such as the All-Ukrainian Business Tournament "Company Strategy"24 every year it becomes "younger" only confirms our conclusions. In addition to career guidance work with children, it is appropriate to strengthen the "entrepreneurial" component of the training of high school graduates. We believe that the requirement to develop and implement at least one entrepreneurial project by each university student (of course, taking into account the specifics of professional training) is absolutely acceptable. Such projects allow not only to ensure the formation of the so-called "soft skills", which have become an integral professional characteristic of a graduate of a modern university, but can also solve various social, environmental, cultural and other problems of individual communities.

2. The formation of entrepreneurial competencies should be based on the comprehensive development of the personality, it involves not only the acquisition of knowledge about the laws and laws of the economy, the development of techniques and methods of work in the field of creating public goods, but also the decomposition of the socalled "soft skills" - teamwork abilities, intercultural competence,

\footnotetext{
${ }^{23}$ Galvan, C. Global Competitiveness Report (2015-2016). Retrieved Oct. 14, 2019, from http://lpk.lt/wpcontent/uploads/2015/12/20151201_Global-Competitiveness-Report-2015-2016_Caroline-Galvan.pdf

${ }^{24}$ Biznes-turnir "Stratehiia firmy". [Business tournament "Firm strategy"]. Retrieved Nov. 20, 2019, from http://kint.com.ua/ua/biznes-tour-stratehiiafirmy-20 [in Ukrainian]
} 
"Lifelong learning" and others. The formation of such characteristics is successfully achieved including using digital technologies (various business simulators, social networks, online communities, etc.) and the expansion of the forms of collaboration (Table 1). Extremely interesting in this context is the experience of implementing the model of coeducational learning, which was acquired by its participants according to the results of the Ukrainian-Canadian educational and research project implemented at the Kyiv National University of Economics named after Vadim Hetman in $2016^{25}$.

Table 1

The most common forms of collaboration in education ${ }^{26}$

\begin{tabular}{|l|l|}
\hline \multicolumn{1}{|c|}{$\begin{array}{c}\text { Types of } \\
\text { collaboration }\end{array}$} & \multicolumn{1}{c|}{ Types and content of interaction } \\
\hline Academic mobility & $\begin{array}{l}\text { Involvement of university professors and researchers } \\
\text { in working in the business environment, and } \\
\text { employees of companies - in the educational process }\end{array}$ \\
\hline Student mobility & $\begin{array}{l}\text { Establishment of conditions for training and } \\
\text { internships in business and / or other educational } \\
\text { establishments for professional development and } \\
\text { development soft skills }\end{array}$ \\
\hline R\&D collaboration & $\begin{array}{l}\text { Carrying out joint research involving a wide range of } \\
\text { stakeholders (researchers from different institutions, } \\
\text { business representatives, students, etc.) }\end{array}$ \\
\hline $\begin{array}{l}\text { Commercialization } \\
\text { of results R\&D }\end{array}$ & $\begin{array}{l}\text { Patenting, licensing, spin-offs, deployment of } \\
\text { intermediary platforms between research centers and } \\
\text { business }\end{array}$ \\
\hline $\begin{array}{l}\text { Development of } \\
\text { educational programs } \\
\text { and curricula }\end{array}$ & $\begin{array}{l}\text { Collaboration of universities with the labor market } \\
\text { (business) in the formation of educational products } \\
\text { for different levels of training of future professionals }\end{array}$ \\
\hline $\begin{array}{l}\text { Entrepreneurial } \\
\text { initiatives }\end{array}$ & $\begin{array}{l}\text { Universities' activities aimed at creating new } \\
\text { ventures and cooperating with business to develop } \\
\text { innovative entrepreneurship culture }\end{array}$ \\
\hline $\begin{array}{l}\text { Long Life Learning } \\
\text { Projects }\end{array}$ & Adult education \\
\hline
\end{tabular}

\footnotetext{
25 Blayone, T. J. B., Mykhailenko, O., vanOostveen, R., Grebeshkov, O., Hrebeshkova, O., \& Vostryakov, O. (2018). Surveying digital competencies of university students and professors in Ukraine for fully online collaborative learning. Technology, Pedagogy and Education, 27(3): 279-296. http://dx.doi.org/10.1080/1475939X.2017.1391871

26 Pokidina, V. (2016) Universytety ta biznes: mizhnarodnyi dosvid spivpratsi ta perspektyvy dlia Ukrainy [Universities and Business: International Collaboration Experience and Prospects for Ukraine]. Retrieved Nov. 18, 2019, from: http://www.cost.ua/news/421-college-business-cooperation [in Ukrainian]
} 
3. Entrepreneurial education is a fertile field for the dissemination of electronic learning technologies (distance education, online courses, professional online communities, etc.), since the latter allow for the maximum optimization of the applicant's time resources and simultaneously implement their business projects. The use of online learning technologies allows not only to change the model of professional training of future entrepreneurs, but also to create in them the digital competences necessary for successful activity in the conditions of post-industrial economy. By the way, the software industry is the only sphere of economy of Ukraine which steadily increases volumes of export of the services ${ }^{27}$. For example, implementing online courses based on business platforms similar to Microsoft Office 365 (for example, the basics Class Notebook ${ }^{28}$ ), allows you to achieve educational goals while developing a culture of business communication and mastering professional business applications of the highest level.

4. The creation of proper motivation for the development of entrepreneurship as a professional sphere for all participants in the educational process is one of the most difficult problems of our time. As our experience shows, students easily lose their incentives to study if educational materials become available to them in an online format. In turn, teachers do not see the advisability of using online tools, as they "lose a live connection" with the student. The only way out is to improve and search for radically new (compared with the industrial world) models of the educational process and technologies for implementing the competency-based approach in education. It is necessary to take into account the co-educational model of training, which is very adapted to the challenges of the digital economy and can be highly effective specifically for the needs of business education.

Examples of successful implementation of these initiatives are the Kyiv National Economic University named after Vadim Hetman. In particular, in order to popularize the work of an economist and career guidance work with schoolchildren, the Ukrainian Business Tourney "Company Strategy" has been held since 2013, which is implemented on the basis of a virtual business simulation VIAL $+{ }^{29}$. For more than ten

\footnotetext{
${ }^{27}$ Ohliad ekonomiky Ukrainy - 2018. [Review of the Ukrainian Economy - 2018.]. Retrieved Nov. 2, 2019, from http://www.chamber.ua/Content/Documents/-1635684409Country_Profile_2018_UA.pdf [in Ukrainian]

${ }^{28}$ Hrebeshkova, O. M. (2017). Onlain-kurs na platformi OneNote Class Notebook. [Online course on the OneNote Class Notebook platform.]. Retrieved Sep. 21, 2019, from https://blendedlearning.teachable.com/ p/onenote [in Ukrainian]

${ }_{29}$ Biznes-turnir "Stratehiia firmy". [Business tournament "Firm strategy"]. Retrieved Nov. 4, 2019, from http://kint.com.ua/ua/biznes-tour-stratehiiafirmy-20 [in Ukrainian]
} 
years, on the basis of the educational and training center of economics and enterprise management, professional training programs have been implemented for economist students based on virtual business simulations (Sigam Market, "Clash of the Titans"30) and special professional software products (1S, Diamond FMS, Power BI etc.). In order to educate entrepreneurs of the new generation, the opening of the master's program "Entrepreneurship in Educational Activities" was initiated, one of the key tasks of which is to create competencies among entrepreneurs to create digital educational products.

Regarding the development of the digital competence of university teachers, the significant contribution of special continuing education programs, the introduction of online training based on MOODLE, the dissemination of the experience-sharing experience based on projects such as the Laboratory for Innovative Educational Technologies ${ }^{31}$ should be noted and information platform "Innovation in business education" Therefore, a complete chain of coverage of all levels of educational activity - from schoolchildren to qualified professionals - has been built almost.

\section{CONCLUSION}

The formation of the digital competence of an entrepreneur in Ukraine is a task that can be solved only from the perspective of a systematic approach and on the basis of strategic partnership of a wide range of stakeholders - government agencies, educational institutions and business. The success of this task depends on many exogenous and endogenous factors, among which the most influential are:

a) institutional support for educational reforms;

b) further development of the digital infrastructure in the country;

c) the formation and dissemination in society of an entrepreneurial paradigm of thinking, involving proactive behavior of economic entities, a creative approach to solving problems, readiness for change and learning throughout life;

\footnotetext{
${ }^{30}$ Biznes-symuliatsiia "Bytva tytaniv". [Business simulation "Battle of the Titans".]. Retrieved Nov. 4, 2019, from https://meim.kneu.edu.ua/ua/depts6/mijnar_obliku_auditu/news_of_department_moba/buz_simul/ [in Ukrainian]

${ }^{31}$ Laboratoriia innovatsiinykh osvitnikh tekhnolohii. [Laboratory of innovative educational technologies.]. Retrieved Nov. 6, 2019, from https://www.facebook.com/profile.php?id=869017436494282\&ref=br_rs [in Ukrainian]

32 Informatsiina platforma "Innovatsii v biznes-osviti". [Business Education Innovation Information Platform]. Retrieved Nov. 10, 2019, from https://www.facebook.com/ibecon/ [in Ukrainian]
} 
d) increasing the digital competence of entrepreneurs as a result of the active introduction of modern models of education (including e-learning) at all its levels;

e) the transformation of the content of education towards the deployment of a competency-based approach and problem-oriented learning.

\section{SUMMARY}

The study of the formation of digital competence of entrepreneurs was carried out on the basis of studying the practice of implementing educational innovations by Ukrainian universities. The experience of transformational changes in the educational process of one of the leading economic universities of Ukraine, Kyiv National Economic University named after Vadim Hetman, is summarized. The results of the introduction of the blended learning model are presented and the effectiveness of using e-learning tools in the educational process of the university is analyzed. The proposals on building the capacity of educational innovations in the formation of digital competence of future entrepreneurs are formulated.

\section{REFERENCES}

1. 5 hlavnykh urokov Kremnyevoi Dolyny. [5 main lessons of Silicon Valley]. Retrieved Nov. 1, 2019, from http://www.startup.org.ua/ 2016/04/5.html?m=1 [in Russian].

2. Biznes-symuliatsiia "Bytva tytaniv". [Business simulation "Battle of the Titans".]. Retrieved Nov. 4, 2019, from https://meim.kneu.edu.ua/ua/depts6/mijnar_obliku_auditu/news_of_depa rtment_moba/buz_simul/[in Ukrainian]

3. Biznes-turnir "Stratehiia firmy". [Business tournament "Firm strategy"]. Retrieved Nov. 20, 2019, from http://kint.com.ua/ua/biznestour-stratehiiafirmy-20 [in Ukrainian]

4. Blayone, T. J. B., Mykhailenko, O., vanOostveen, R., Grebeshkov, O., Hrebeshkova, O., \& Vostryakov, O. (2018). Surveying digital competencies of university students and professors in Ukraine for fully online collaborative learning. Technology, Pedagogy and Education, 27(3): 279-296. http://dx.doi.org/10.1080/1475939X. 2017.1391871

5. Brodovskaia, E. V., Azarov, A. A., Dombrovskaia, A. Yu. \& Dmytryeva, O. V. (2014). Sotsyalnyi kompiutynh: istoryia, metodolohyia, yssledovatelskye proekty. [Social computing: history, methodology, research projects.] Doklad na 18-m zasedanyy semynara 
"Metodolohycheskye problemy nauk ob ynformatsyy". Moskva, YPHYT MHHU ym. M.A. Sholokhova. Retrieved Sep. 1, 2018, from https://docplayer.ru/33551421-Socialnyykompyuting-istoriyametodologiya-issledovatelskie-proekty.htmt [in Russian]

6. Compare Countries. Hofstede Insights. Retrieved Nov. 16, 2019, from https://www.hofstede-insights.com/product/compare-countries/

7. Galvan, C. Global Competitiveness Report (2015-2016). Retrieved Oct. 14, 2019, from http://lpk.lt/wp-content/uploads/ 2015/12/20151201_Global-Competitiveness-Report-20152016_Caroline-Galvan.pdf

8. Global Entrepreneurship Index. Retrieved Nov. 21, 2019, from http://thegedi.org/countries

9. Hrebeshkova, O. M. (2017). Mikroekonomika: pochatkovyi riven. [Microeconomics: entry-level]. Retrieved Nov. 10, 2019, from https://www.udemy.com/microeconomics_ua. [in Ukrainian]

10. Hrebeshkova, O. M. (2017). Onlain-kurs na platformi OneNote Class Notebook. [Online course on the OneNote Class Notebook platform]. Retrieved Sep. 21, 2019, from https://blendedlearning.teachable.com/ p/onenote [in Ukrainian]

11. Hrebeshkova, O. M. (2018). Praktyka zmishanoho navchannia v navchalnomu protsesi na fakulteti ekonomiky ta upravlinnia DVNZ "KNEU imeni Vadyma Hetmana". [The practice of blended learning in the educational process at the Faculty of Economics and Management of the KNEU named after Vadym Hetman]. Dopovid na zasidanni vchenoi rady fakultetu (22.11.2018 r.). Retrieved Nov. 2, 2019, from https://drive.google.com/file/d/1Hkl783HCvhLfMRUgU8hWaHvANCb PpqLv/view?usp=sharing [in Ukrainain]

12. Hrebeshkova, O. M. Yak stvoryty onlain-kurs v Microsoft OneNote Class Notebook. [How to Create an Online Course in Microsoft OneNote Class Notebook]. Retrieved Oct. 24, 2019, from https://www.udemy.com/onenote-classroom/learn/v4/overview. [in Ukrainian]

13. Hrebeshkova, O. M., Grebeshkov, O. M. \& Kyzenko O. O. Onlain-kurs "Zmishane navchannia: retsepty - prosto ta smachno! Znaiomstvo z "kukhneiu" zmishanoho navchannia". [Blended Learning: Recipes - Easy and Delicious Online Course! Getting to know the blended learning kitchen.']. Retrieved Nov. 4, 2019, from https://blendedlearning.teachable.com/p/blendedlearningrecepies. [in Ukrainian] 
14. Informatsiina platforma "Innovatsii v biznes-osviti". [Business Education Innovation Information Platform]. Retrieved Nov. 10, 2019, from https://www.facebook.com/ibecon/ [in Ukrainian]

15. Karpenko, O. (2017) Hlava Alibaba Dzhek Ma - ob ekonomyke budushcheho: "Perestante nadeiatsia na proyzvodstvo $\mathrm{v}$ sozdanyy rabochykh mest". [Alibaba CEO Jack Ma, on the economy of the future: "Stop hoping for manufacturing in job creation."]. Retrieved Oct. 23, 2019, from https://ain.ua/2017/09/21/dzhek-ma-ob-ekonomikebudushhego/ [in Russian].

16. Kontseptsiia rozvytku tsyfrovoi ekonomiky ta suspilstva Ukrainy na 2018-2020 roky. [Concept of development of digital economy and society of Ukraine for 2018-2020.]. Retrieved Nov. 10, 2019, from http://me.gov.ua/Documents/Download?id=f9605f2f-c4a846f3-aee9-4a7f40dc9b9b [in Ukrainian].

17. Kyzenko, O. O. (2017). Kurs video-lektsii "Korporatyvne pidpryiemnytstvo". [Course of video lectures "Corporate entrepreneurship".]. Retrieved Nov. 10, 2019, from https://www.youtube.com/ watch? $\mathrm{v}=$ Leal95BNOBQ\&list=PLgBzM3 YOp1EGBcMs8xrNaedoTEcUJ gkzh [in Ukrainian]

18. Laboratoriia innovatsiinykh osvitnikh tekhnolohii. [Laboratory of innovative educational technologies.]. Retrieved Nov. 6, 2019, from https://www.facebook.com/profile.php?id=869017436494282\&ref=br_rs [in Ukrainian]

19. Maximizing the impact of digitization. PWC. Retrieved Nov.10, 2019, from https://www.strategyand.pwc.com/media/file/Strategyand_ Maximizing-the-Impact-of-Digitization.pdf

20. Mesenbourg, T. L. (2001). Measuring the Digital Economy. U.S. Bureau of the Census.

21. Ohliad ekonomiky Ukrainy - 2018. [Review of the Ukrainian Economy - 2018.]. Retrieved Nov. 2, 2019, from http://www.chamber.ua/ Content/Documents/-1635684409Country_Profile_2018_UA.pdf [in Ukrainian]

22. Pasichnyk, O. (Ed.) (2017). Praktyky zastosuvannia zmishanoho navchannia $u$ vyshchii shkoli: analitychnyi zvit za rezultatamy opytuvannia [The practice of capturing the meaning of food in high school: an analytical call for the results of the study]. Tsentr navchalnykh ta innovatsiinykh tekhnolohii Ukrainskoho katolytskoho universytetu Retrieved Aug. 16, 2018, from http://er.ucu.edu.ua/ handle/1/1124 [in Ukrainian] 
23. Pokidina, V. (2016) Universytety ta biznes: mizhnarodnyi dosvid spivpratsi ta perspektyvy dlia Ukrainy [Universities and Business: International Collaboration Experience and Prospects for Ukraine]. Retrieved Nov. 18, 2019, from http://www.cost.ua/news/421college-business-cooperation [in Ukrainian]

24. Savery, J. R. (2006). Overview of Problem-based Learning: Definitions and Distinctions. Interdisciplinary Journal of ProblemBased Learning, 1(1).

25. Taşoğlu, A. K. \& Bakaç, M. (2014). The Effect of Problem Based Learning Approach on Conceptual Understanding in Teaching of Magnetism Topics. Eurasian Journal Physics \& Chemistry Education 6(2): 110-122.

26. Ukrayna na 42-m meste $\mathrm{v}$ reitynhe ynnovatsyonnыkh ekonomyk myra. Kak tak vyshlo? [Ukraine is at 42nd place in the ranking of innovative economies in the world. How did it happen?]. Retrieved Nov. 9, 2019, from https://businessviews.com.ua/ru/economy/id/ukraina-na42-m-meste-v-rejtinge-innovacionnyh-ekonomik-mira-kak-tak-vyshlo1460/ [in Russian]

27. Yskandarova, D. M., Hulova, Z. A., Davlatmyrova, M. B., Karymova, N. Y., Mukhtorov, Z. M. \& Fomyn, A. Yu. (2016). Yssledovanye tolerantnosty $v$ molodezhnoi srede Tadzhykystana (lynhvystycheskye aspekty). [The study of tolerance in the youth environment of Tajikistan (linguistic aspects)]. Moskow: Yzdatelskyi dom Akademyy Estestvoznanyia [in Russian]

\section{Information about the authors: Hrebeshkova O. M.}

Candidate of Economic Sciences, Associate Professor, Department of Business Economics and Entrepreneurship,

SHEE "Kyiv National Economy University named after Vadym Hetman", Ukraine ORCID: http://orcid.org/0000-0002-6896-3941

Kyzenko O. O.

Candidate of Economic Sciences, Associate Professor, Department of Business Economics and Entrepreneurship,

SHEE "Kyiv National Economy University named after Vadym Hetman", Ukraine ORCID: https://orcid.org/0000-0002-6109-4798 